\title{
The Independence of the Labour of Women in Strengthening the Economy in Indonesia
}

\author{
Hasbiyadi, Patta Rapanna, Mustafa Gani \\ Lecturer at the high school of Economics Makassar (STIEM Bongaya) Makassar, Indonesia
}

\begin{abstract}
:- types of qualitative research approach through Phenomenology, as for the shows research results that women workers are there in Indonesia is one of the underpinning of the economic crisis, various family the economy happens on the rising needs imposes an economic family, so for addressing many of the mother house of then working, in fact the award going to the right the rights of women have not been getting the respect of employers who hire them, so that the issues of continuous public spotlight got both locally, nationally and internationally.
\end{abstract}

Keywords:- Independence, Women, Economic Policy.

\section{INTRODUCTION}

One of the many informal sector employment group of women, especially mothers of households, i.e. work in the system of putting out, namely the wholesale system carried out in homes. The status of the mother as a home-based workers (home based worker). Today, home-based work system into a model of stable production and profitable for entrepreneurs, because it saves a lot of proven production costs amounted to $30-40 \%$.

Related assumptions housewife formed in society is inseparable from the responsibility of women, such as domestic work over parenting, cooking, and took care of the House, to the resulting term kanca wingking (women as friend in the back) in the life of Javanese (Darwin, 2005:64). Therefore work as home-based workers, such as sewing and knitting media distribution is assumed as hobbies women's incomes to help the economy of the family.

Home-based workers who have not been recognized the status of the workers by the Government as well as the low awareness of critical labour home over his rights as workers, home workers Often have to work overtime to supplement their income in insufficient the needs of families and to meet the demand increases the number of entrepreneurs in the production effort without getting additional wages overtime work of entrepreneurs (Wan, 1997:26).

See the life of home-based workers are relatively prosperous, not many labour institutions have concern for the workers ' home, one of which is the ILO (International Labour Organization). Although the ILO had ratified the existence of home-based workers as workers, the ILO Convention on home-based labor related 1996 has not been ratified by the Government of Indonesia, so that home-based workers not yet recognized as workers. As a result, home-based workers have yet to obtain the legal protection and social security provided by the Government of Indonesia. Low country surveillance system in the form of laws, cause the position of the entrepreneurs is very benefited, because they do not have the system of working relationships.

\section{A. Formulation of The Problem}

- How did the economic independence of female Labour in Indonesia?

\section{A REVIEW OF THE LITERATURE}

\section{A. The Role of Women}

In the public sector, the common problems faced by women in employment is the propensity of women marginalized in these kinds of jobs are low wages, poor working conditions, and have no job security. This applies specifically to women are educated middle to bottom. Jobs in the city are as factory laborers, while in the countryside as peasants. It needs to be underlined here is that the tendency of women marginalized in such marginal job is not solely due to the education factor. From among the entrepreneurs themselves, there is a preference for hiring women on certain sectors and certain types of jobs because women's wages were lower than men's.

Another reality can also be shown on the labor of women in the informal sector which is irregular and workplace organized. In these circumstances, the labour of poor women more often experience exploitation than male labour. In the rice fields of Southeast Asia, for example, women received wages one-third lower than the men for the same job, facing sexual harassment, work continued during pregnancy and childbirth, as well as do not have the assurance of salvation and Health (Khusnul,2009).

Women have the potential in contributing household income, particularly poor households. In poor households members household women plunge into the job market to augment household income perceived is not enough. Increased participation of women in economic activities due to: first, any change of views and attitudes about the importance of equal education for women and men, as well as the more he need women participated in development, secondly, the existence of women's willingness to stand alone in the field of economics that is trying to finance the needs of his life and perhaps also the necessities of life of the people who become his charge with his own earnings. Another possibility is causing an 
increase in the participation of women in the work force is increasingly the breadth of employment opportunities that could absorb the women workers, such as the emergence of crafts and light industry (in Sugeng, 2008).

\section{B. Decision-making}

Is decision (decision) is the means of choice (choice), that is a choice of two or more possibilities. Although the usual decision is said to be the same as the options, there are important differences between them. MC Kenzei saw that the decision is a real option because the option is defined as the choice of destinations including options on how to reach that goal, whether at the individual or collective level. MC Grew more and Wilson looked at the relation to process, namely that a decision is the end of a process that is more dynamic, labeled the decision making. Because the process is seen as consisting of a series of related activities and not only considered as an act of wisdom.

Morgan and Cerullo defines decision as a conclusion reached after done the consideration, that occurs after the selected one possibility while others are ruled out. Decisionmaking is the process of selecting an alternative way of acting with an efficient method suitable situation. The process to find and solve the problems of the organization. A key rule in decision-making is the right framework once it's been settled, decisions must be made. In other words, a decision he accelerates the action, prompting the birth of movement and change.

Decision making should be understood in the sense of two namely (1) the purpose of the assignment is the translation of the goals, aspirations and (2) the achievement of the goals through implementation (Inbar,1979). In summary the decision is made to achieve the goal through the implementation of this and all centered on the relationship of humanity. For successful decision making it then the ten commandments of humanitarian relationship should be a reference from any decision making.

\section{The Decision Making Process}

There are two views in the achievement process of reaching a decision the Organization, namely:

Optimization. Here an Executive full confidence trying to devise alternatives, taking into account the profit and loss of each alternative against the goals of the organization. Then estimate the likely incidence of various events in the future, consider the impact of the events of alternatives that have been formulated and then compile the sequence systematically in accordance with priority and then made a decision. Decisions made are considered optimum because at least has been taking into account all factors relating to the decision.

The Satisficing. An Executive simply sitting for a settlement that comes to satisfy rather than pursuing settlement. Satisficing model developed by Simon because of the recognition of limited rationality (bounded rationality). Rationality is limited to the boundaries of thought forcing people restrict their view on the matter and the situation. Thought it was limited because the human mind does not formulate these and have the ability to separate the stack information.

According to Frank Harison, factors that cause the onset of limited rationality among others information coming from outside is often very competitive or the information was not perfect, time constraints and costs, as well as the limitations of a take a rational decision to understand and grasp the issues and information, especially of information and technology.

\section{RESEARCH METHODS}

This type of research is a Qualitative phenomenological approach through the data sources in this study include: the source of primary Data and Secondary Data sources. This is a research instrument of the researchers themselves, which researchers as an instrument to get accurate data provided by various methods.

\section{DISCUSSION}

The nature of women is part of life and life partner a nice guy in love or grief. In the view of life in the world women are always portrayed as a gentle, loving and patient. Let's see our mother, she's a woman who is closest and understand everything about us. Take a look at how meritorious a mother, woman containing us, raising us with loving and always forgive us even though we frequently disappoint him. See all statements above certainly should have no more forms of discrimination-discrimination and difference in attitudes towards women. But in fact the forms of discrimination against women is still very visible.

Discrimination against Women CEDAW Convention there are 12, according to the forms of discrimination namely (1) women and poverty; (2) education and training of women; (3) women and health; (4) violence against women; (5) women and armed conflict; (6) women and the economy; (7) women in power and decision-making; (8) the institutional mechanisms for the advancement of women; (9) the human rights of women; (10) women and the media; (11) women and the environment; and (12) girls.

Numerous attempts have been made to abolish the twelve forms of discrimination, inter alia concerning violence against women established by Act No. 23 of year 2004 in September 2004 on the Elimination of violence in the Home Ladder. In addition, in support of the effort of elimination of discrimination, in the national legislation Programme (Prolegnas) in 2005 will be discussed the various draft laws relating to the Elimination of discrimination against women, among others Bill on Immigration, a bill on health bill on pornography and Porn action, and Bill on the statute book of 
the criminal law. But all this has not been able to complete a variety of forms of discrimination of women as a whole.

Women's issues actually been widely highlighted by observers both women present national and international. Study of women every year languid debated so that women can go to a wider world than ever before, because the supposed most women only suitable working on domestic sectors such as parenting, cooking, and other household work as for the male job was working as a public sector employee, employees, entrepreneurs, politicians and others. At the time of global assumption is less precise existence for whatever he man can also be done by women.

Every labor day worldwide in various cities around the world looks down to the street action carried out by the labour of women. They demanded that the companies not apply discrimination between women's labour. Labour women working in a factory many experienced discrimination than male labour. Most women experience labor pressure among workers in the factory, many of the discriminatory treatment of female workers, for example, are still widely employed the evening even till two in the morning hours, whereas in the law are not allowed. The reason, target only employment of women workers are not being met. The question of the fundamental rights of the still very difficult labour women obtained. It is the basic right of pregnant and on leave when the menstruation. But there are still many laborers who can't enjoy it, to get them the process will be compounded. Various other labour discrimination women still become plural are found. Starting from the standard lower wages than male labour wages, severance benefits, such as the lack of an accepted male labour, to work in the form of skors overtime without getting paid if you do not meet the target of the work, which defined arbitrarily by the company.

One form of discrimination in the job market that much got a spotlight is wage discrimination according to gender. The company considered doing a differentiation of wages without objective criteria or relating to workers ' performance. For example the practice of wage discrimination between women with men among peasants, has been running since long time. Dunno who initiates, peasant women were given a reward worth about 75 percent of the wages of male peasants. Though not a few types of jobs in the agricultural sector are in General better result if done for women. That is, the difference in productivity is not the reason for the wage discrimination.

Now, after all this time the movement of the Elimination of all forms of discrimination such as the winds its way, very interesting to see if the practice of wage discrimination still occurs. Also interesting see if government policies can play an important role in the Elimination of wage discrimination. Allegations of wage discrimination could not immediately addressed to entrepreneurs. There are two situations that are indeed related, but it can be distinguished from each other, i.e. the wage discrimination and employment discrimination. Wage discrimination is discrimination on the job, workers ' wages, hours of work, performance, as well as other conditions that are all the same. Thus, the differentiation of wages is done solely because of gender considerations. Meanwhile, job discrimination knows no distinction of wages between men and women for the same job, but restrict access of women in certain jobs.

More specifically, women were only given access to jobs of low quality, where salary (wages) are lower. There are a variety of reasons companies do the job discrimination. First, prejudice a particular job can only be done man, or male fit only do work. This can be seen in job advertisements in various media. Secondly, the rules on women workers ' rights, so that women workers be considered recruiting "detrimental " company. For example, rules about furlough leave, especially menstruation and maternity leave. On the one hand, regulation is positive, because it protects women workers associated with reproductive function. However, from the point of view of the company, these provisions create potential women workers have working days lower than men, while his salary should continue to be given when on leave.

\section{A. Economic Independence of Women Workers In Indonesia}

In this era of globalization the independence of women is urgently needed. Women often get stereotyped (labeling) as konco wingking, was shifted to become an independent woman. Eco Setyowati Abbas Rochim as activists set of young entrepreneurs (HIPMI) Indonesia said that with advances in science and technology are no limit encourages women in particular, to be more creative, the existence of gender equality which had long championed, will certainly have an effect on businesses that do women the public area.

First, Networking. Women tend to be more easily in building relationships (networking), particularly in partnering in the business world.

Second, Creative. Usually a woman has lots of ideas and ideas that can be developed, primarily for business matters. They're not going to run out of ideas for making an effort. Communication is maintained by a woman usually always update. When hanging out with their friends, it's usually the woman always discuss something new, unique, and creative.

Third, Tlaten. Uniquely, women have a higher level of accuracy than the House of Adam. Both in financial problems, as well as the business problem that the one ato. At least, women are able to become manager that joss for every business that is conducted. Good online business, home business, any business it's.

Back again with Bu Eko of the HIPMI, she says that the HIPMI offers cooperation to the young entrepreneur to join them. With the purpose of developing HUMAN RESOURCES, increasing mentoring to seek assistance in capital, as well as product marketing development program up to the global market HIPMI will help realize the dreams of aspiring entrepreneurs who want to achieve success. 
In addition HIPMI also aims to score a formidable businessman in the face of global competition, increasing interest in entrepreneurship, as well as print out the innovative and creative entrepreneur.

Similarly, with the utterance of the Mother Goddess Feb. Kustijanti of LRC-KJHAM, hope to women, in realizing economic independence are expected to embody a developed nation and dignified. He added, with the economic independence of women, women can be expected to suffice the needs of his own personal needs, enhance especially the worship of self, making it more usable, as well as improve the bargaining position as the a female.

So much of the problem of Domestic Violence caused by the economic problems. Women entrepreneurship in fact not solely to compete in terms of income with the spouse. However, it was all rather to how women are not hanging with the womenfolk, do not always ask couples when we need money.

The institution known as the CCDE (Center for Community Development and Education) of Banda Aceh. Institutions that very concern and committed against women's and children who are less fortunate. CCDE provide interventions and service through alternative education activities, media and publishing economic development for women and children that his form is a magazine portrait and children's magazines.

Imagine, women as the party that commissioned and very responsible with domestic affairs, is in fact a heavy job should run. Although some view it with viewpoints, only range in three domains, a well, a kitchen with a mattress, but truly, if we create a list of activities that then clearly we see how it weighs the duties and work or women at home.

Not wrong if anyone says that's "women's work or the mother in the House, starting from before sunrise until sunk eyes husband ". In these conditions, women sometimes have to have impossible hands, yes not quite two hands, but it should be a lot of hands. So very heavy isn't it? Of course the weight, but not many people saw it. Some even said, women at home, just sitting around. Certainly very ironic.

Then, when a lot of women now consciously and forced out of the realm of domestic, and plunge into the realm of the public into taking the role of women in the economic sector, to become women's small businesses and others that are in the public domain, then whatever they did that showed that women have a great potential and role in the economic sector, especially at the microeconomic level.

Therefore, remember your preferred that they have huge potential and potential, this potential should be greater attention from all parties concerned, including the Government and even the Office of empowerment and child protection. This service, could be more creative activities program provides increased capacity of women's small businesses in each area.

\section{B. Important economic independence}

See intentions and noble work performed by women's entrepreneurship, in essence, every woman should be implanted consciousness that what was done by women with small businesses that they are concluding, is not merely a helpful husband. Women in conditions like this now, can no longer position themselves as the recipient and the provider of a living brought husband. Women it is a figure that is strong and has great economic potential, let alone most of the women working in the informal sector and microenterprises for proved able to survive, though beset by economic crisis. Therefore, the potential of existing ones need to be developed and improved its quality.

The woman should also be reminded that the work and the intention to help the husband was important and glorious, but more importantly for the woman herself is the willingness to build women's economic independence itself. It is said so, because when women have economic independence itself, meaning that women have their own income or income. Moreover, if you can set your own income earned, would be very helpful to women. By having economic independence, women will be able to release the economic dependence on husbands.

With economic independence which is owned by every woman must also be releasing the possibility of double burden that may appear, when women should work with their entrepreneurial activities. Women's small businesses, should be able to reduce the burden of domestic work with potential and financial independence that they belong to from the results of their efforts.

It is important to remember that, as long as it actually although in all things in the household, women tend to rely heavily on a living being carried or administered by the husband, surely also should keep in mind that not always a woman continues Depending on the income of the husband. If her husband is still alive and well or still have earnings, when all of a sudden illness, no longer able to work, or died, then women who have no economic independence, will hard, helpless. Anyway it must be understood that in life nothing is eternal.

\section{The Role of Government}

The reduced durability of this latter family did not escape from the lack of attention the Government in educating and encouraging the public to realize the optimization of the family healthy. The role of Government, in this case the national family planning Coordination Board (BKKBN) that look hasn't been able to realize an order and healthy and prosperous family models are applicable. So the target this time is also very BKKBN quantitative and haven't touched it 
to the root of the problem namely how to create healthy and prosperous family resilience intact.

As institutions that are expected to contribute to the strengthening of family resilience, BKKBN is supposed to be able to make blueprints family in Indonesia. So that we can see and measure how much the population of families that have been independently both mentally as well as material, which is certainly not just judging from the number of children. This is important given the problems of family resilience not only because of the number of children that belong to it, but further than that is how parents play a role in parenting, nurture and educate family members optimally.

It also recognized during the BKKBN has had a series of programs the resilience and empowerment of families. But the point of the press of this program only on resilience and economic empowerment, less touched on aspects that facilitate in setting up a family character. This condition could be due to the presence of many institutions that deal with the family but poor coordination and communicate.

At the same time, BKKBN experienced various constraints along with the domestic politics of social change, including change of the pattern of centralization becomes decentralized where County Government and City are now authorized in the exercise of Family planning program (KB). So the success of family resilience relies heavily the extent of the commitment of the heads of the regions and the REPRESENTATIVES of concerned in carrying out this program. If the Governors, mayors and regional legislatures are not running this family resilience programs as priority, then the task of BKKBN may be only a story.

\section{- Family Healthy}

Besides the factors that caused the waning family resilience is the weakening of values and morality. example. These factors cause the family atmosphere does not give positive expectations for the behavior of family members. This example and morality factor becomes important because the fact even though a family economically quite capable yet the behavior of life family members there who are experiencing not happy. Similarly, changes in the pattern of life, the invasion of globalization and the effects of mass media has contribute to weaken the resilience of the family at this time. Speaking of family resilience is certainly not escape from the role of the family is healthy and productive. Healthy of course not only in terms of meeting the needs of the economy are pretty but more than just that. Healthy families is ideal where all members of the family unit capable of providing a positive influence well into the family itself or the surrounding environment. In the teachings of the religion we know the slogan "jannati baiti district" as a reflection of how the House should be made a positive arena for increases the and channeling the potential of every Member of the family. Family interactions are managed so that gave birth to the solidarity so that a firm's management was able to scrape the seeds of fractured family.

Of course it is not easy to form a profile of healthy families like this in the middle of the social conditions and economic pressures. Healthy family characters at least can be realized through the interaction example, trust an excellent communication within and outside the family environment. In essence, the family was able to exist and provide a reciprocal influence for the formation of an ideal character family members and their surroundings. Religion also teaches us to make a profile of the family as a social unit which can be helpful for family members and others so will bring up the authority and role of the family in the social order of society. If a profile of the family ideal is embodied by the nuclear family then social disease phenomenon appears in Indonesia very likely would be reduced.

\section{- $\quad$ Solution Strengthening one's family}

Awareness of the importance of a healthy and productive families lead us to perform strategic steps in order to realize the noble ideals. First, the Government should conduct a reorientation of development families with clear blueprint family-profile Indonesia is healthy and productive, which pay attention to the balance between religiosity, mental factors are economic and social. Once again it is becoming important because easy not happy family of Indonesia is not solely due to economic factors but a result of the problem-a very complex problem.

Second, to clarify the Division of tasks, authority and function of the related institutions of the estuary program on development of the family. Each agency should have programs, budget and personal, but no less important is the coordination of these institutions, hence the required appointment of one institution as the Coordinator to coordinate the programme in order to doesn't happen to overlap as well as each other loose hand in its implementation Third, do strengthening autonomous region by improving the quality of human resources and other resources so that the expected implementation of the autonomous region are getting a quality based on a more comprehensive understanding of the substantive and about the meaning of the autonomous region. At the same time the Central Government is required to be able to convince the local government that the program on resilience and empowerment of the family is a long term investment and strategic value to the well-being of communities in the regions. We hope solutions strengthening family resilience into national issues so that all parties are able to engage in a dynamic and constructive in an effort to realize the family more quality and Indonesia advanced. A family full of affection, solidarity, religious and productive is expected to counteract the problem of acute family institution so that it can bring this nation into a better direction.

- Building Economic Independence 
One of the Government's policy of the past that still feels its effects until now for women is the implementation of national economic policies with an emphasis on aspects of growth that relies on a great effort as the driving force of the national economy. The Government's focus to great effort to contain the notion of granting facilities to the huge effort in running his business, which thus weakens the competitiveness of small businesses-micro lot number and many are run by women.

The number of micro enterprises, according to the data of the Ministry of State cooperatives and Micro small and medium enterprises about 41.8 million or about $98.5 \%$ of the total existing business units. However, the micro enterprise sector is generally informal is not seen as part of the national economy. In this case look yet of the existence of the ACT specifically addresses the micro enterprises, in addition to that the Government tends to be a leveler of all types and sizes of micro enterprises.

The policy is a logical consequence of the election of the capitalist paradigm of Prince Development. Various studies show that the integration of developing countries into the capitalist world economy as a whole has resulted in a slowdown in the creation of opportunities and the way women sustain his life through types of subsistence production.

The capitalist system penetration into the rural economy has put the village as poor economic periferi and put women in a dual role with the choice of work and the limited efforts to meet the needs of the family. The findings of the Widuratmi (2003) shows that women's productive work done in the domestic sphere in order to simultaneously complete the domestic tasks. The findings were also shown by AKTIGAASPPUK (2004).

The efforts of the fulfillment of the needs of families who do women through micro enterprises, basically is not the answer to the increased prosperity through the trickle down effect of the capitalist economic system that is applied in the construction of economy. The effort has the support of the State's political and Government in the form of policies, ranging from the most basic such as UUD 45 which guarantee equality (including equal rights between men and women), protection of women through ratification of CEDAW, to government programs "that are in favor of small people", such as pattern and development of program linkages. Associated with the political support of the State and Government, questionable about the consistency and clarity of policies and programs that are rolled out.

In addition to the constraints in terms of policies, the improvement of the economy women still face inequality constraint structure and culture that puts women in a position that is not taken into account. Whereas micro enterprises which most women do on reality was contributing to the State's economy seemed at the time of the economic crisis, as well as contributed to the economy of the family. Therefore, building economic independence of women was a necessity to improve well-being and is expected to lead to equality against other public access.

The abundance of facts and studies showed the vulnerability of women against injustice has inspired the Government as well as private in an effort to empower women. However, many of the things that lead to the empowerment of a group of communities not yet sustainable. Like the review Chambers (1987), saw the construction of a community group that is not related to the ongoing emergence of negative stereotype of agent empowerment as an outsider against local people, and does not involve local people in development activities. The program does not continue into empowerment, since empowering not in accordance with the circumstances and needs of local communities (Chambers, 1987:133-140). As a result, the vulnerable community groups will continue to be chained in the periphery of the helplessness.

In studies of Chambers (1987) formulated a concept of the circle of poverty or vulnerability that is composed of several interrelated aspects, among others, poverty (poverty), a weak physical (physical weakness), vulnerabilities (vulnerability), isolated (isolation), and powerlessness (powerlessness) (Chambers, 1987:109). Thus, the Chambers formulated the poverty and powerlessness that the phenomenon is a structural phenomenon which is complex.

In studies of Khandker (1998) is inversely proportional to the study of the Chambers in criticizing the unsustainable development. Khander exposes about poverty alleviation programs in women's groups in Bangladesh which is sustainable, through micro-credit program, known as the program of Grammen Bank. The study of how the program outlines the Khandker microcredit for women's groups can help women out of poverty, where women can borrow from venture capital through women's cooperative that formed (Khandker, 1998:2).

Microcredit programs since 1976, has provided a major influence on the socio-economic life of the society of Bangladesh in reducing poverty, not only in the Group of women only. Survey to some households in Bangladesh, in addition to increasing the access of women in borrowed capital, also showed an increase in nutrients in the household, increasing access to education of both men and women, and the increasing awareness of wearing contraceptives (Khandker, 1998:37-59). Even micro-credit programs Grammen Bank can help reduce poverty in Bangladesh by as much as 1\% annually (Khandker, 1998:61).

In studies of Nuwirman (1998) outlined the role of local organizations as a means of empowering the community as poverty reduction efforts. The results showed that local economic organizations can develop independently, with the defined religious activities and high levels of emotional closeness, have a major role in empowering the economy of 
rural communities. Social capital found in a field in the form of exchanging goodness between individuals within a group, such as brewers.

The utilization of the social capital in empowering communities has also been studied by Hudayana (2013), in his research on the slopes of Mount Merapi Eruption (post). The existing findings stated that capital social networking community is a strong potential for community empowerment to create self-contained communities. With a strong social capital, community can share information and issues encountered, so they know the issue at hand to devise strategies to solve the problem. With the awareness of self in women, empowerment can be sustainable, because they feel have the same issue and should be solved together anyway.

Study on mentoring women in home-based labor group empowerment efforts, is not a new research. Study of Kazzi et. all. (1990) the focus of the home-based women workers life outlines in Karachi, Pakistan, who works at a clothing industry embroidery. The majority of home-based workers are housewives with age under 20 years. Although home-based women workers received low wages, they remain willing to work as home-based workers, because of the patriarchal culture of the hegenomi of a woman is not allowed to go out of the House, because it is responsible for the work households. Even home-based workers ' jobs become lively group by housewives in Karachi, Pakistan.

Based on the life of home-based workers were vulnerable to unfair treatment, in studies of Bergan (2009) outlines about labor organizing home-based case studies that are in Bulgaria and Turkey who have not received legal protection from the Government, It is important to organize home-based workers. The efforts of NGOS in organizing home-based workers can raise critical awareness of homebased workers to fight for his rights in order not to be exploited time, effort, and cost of production which are not borne by the employers (Bergan, 2009:227). The success of the mentoring activities in the form of grassroots studies like Bergan (2009) has been studied by Princess (2015), where the education capacity in labor groups carrying in Yogyakarta by the Yasanti is able to raise awareness of the critical labour of carrying to fight for his rights in seeking employment.

\section{CONCLUSION}

The role of women in the economic strength of the build family is very important, but in reality in the world of work they have yet to fully get the appreciation it deserves, this is due to an understanding of the position of women has not been fully understood by the employers, existing laws in Indonesia have set up labor discrimination women can be minimized and women workers can be treated properly. But in fact the discrimination and oppression still occurred. For that much needed role of Government in making policies that related to oversee the deployment of existing legislation bearing in mind there are still many companies or entrepreneurs who, despite already knowing the regulations but not execute as expected. Given the need for coaching and assertive sanctions for employers who do not carry out the regulation in order to achieve the welfare of women in Indonesia

\section{REFERENCES}

[1]. Alice h. Eagly and Mary c. Johannesen-Schmidt Marloes 1. van Engen (2003), "Transformational, Transactional and laissez-faire Leadership Styles: A Meta-Analysis Comparing Women and Men", Psychological Bulletin Copyright 2003 by the American Psychological Association, Inc., 2003, vol. 129, no. 4, 569 - 591.

[2]. George b. Graen \& Mary Uhl-Bien (1995), "RelationshipBased Approach to Leadership: Development of LeaderMember Exchange (a VERSION of) the Theory of Leadership over 25 Years: Applying a Multi-Level, Multi-Domain Perspective", Published in Leadership Quarterly 6:2 (1995).

[3]. Khusnul Khotimah (2009), "Gender discrimination against Women In Job Sectors", vol. 4, no. 1, Jan-Jun 2009.

[4]. Steven Kerr \& John m. Jermier (1978), "Substitutes for Leadership: Their Meaning and Measurement", Organizational Behavior And Human Performance 22, 375-403 (1978).

[5]. Sugeng Haryanto (2008), "the active role of women in Household Income Increased poor: case study on Rockbreaking women's DiPucanganak Subdistrict Trenggalek Monument", Journal of Development Economics, vol. 9, no. 2, December 2008.

[6]. Timothy a. Judge, Amy e. Colbert \& Remus Ilies (2004), "Intelligence and Leadership: A Quantitative Review and Test of Theoretical Propositions" Journal of Applied Psychology Copyright 2004 by the American Psychological Association, 2004, vol. 89, no. 3.

[7]. Timothy a. Judge, Joyce e. Bono, Remus Ilies \& Megan w. Gerhardt (2002), the "Personality and Leadership: A Qualitative and Quantitative Review", Journal of Applied Psychology Copyright 2002 by the American Psychological Association, Inc., 2002, vol. 87, no. 4, 765 - 780. Grijns, the man, Machfud, Sugiah., Sajogyo, Pujiwati., Smith, Inesh., Van Valzen, Anita. (Ed.). (1992).

[8]. Gender, marginalization, and rural industries. Employers, workers, family workers and hired servant woman in West Java. Bogor: BOGOR.

[9]. Ikasari. (2004). Empowers the family economy marginally through the development of microfinance. Jakarta.

[10]. Ismawan, Bambang. (2000). Empowering the poor: reflections of an activist of NGOs. Jakarta: Puspaswara.

[11]. Microfinance in Indonesia, Gema PKM Indonesia compiled by, (April 2005).

[12]. The Ministry of cooperatives and SMALL MEDIUM ENTERPRISES (2004).

[13]. Media Women Information Communication Media, equality and Gender Justice. EdisiNo 3, 2004 
[14]. Sjaifudian, Hetifah., Haryadi,?, Maspiyati. (1995). Strategies and small business development agenda. Bandung: Akatiga.

[15]. Van der Wees, Chaterine \& Romijn, Henny (1995). Enterpreneurship and small and microenterprise development for women. In Louise Dignard, Jose Havet. (Ed.). Women in micro-and small scale enterprise development. Colorado: Westview Press.

[16]. Widuratmi, C. Frida. (2003) the thesis was not published. Women's Batik Tulis Uncover patterns of Relationship Skipper - labour and his involvement in a group of Ngos (SHGS) in district of Klaten Bayat. Case Studies Mentoring NGO Bina Swadaya. Women Studies Program, Graduate School Of The University Of Indonesia. Jakarta. 